\title{
Using a Feminist Interpretation of the Bible's Book of Ruth to Address Taiwanese Female Pastors' Financial Autonomy and Self-Esteem
}

\author{
Yu-Fen Lin* \\ The University of North Texas, Dallas, Texas, USA \\ Email: yu-fen.lin@untdallas.edu
}

How to cite this paper: Lin, Y.-F. (2018). Using a Feminist Interpretation of the Bible's Book of Ruth to Address Taiwanese Female Pastors' Financial Autonomy and Self-Esteem. Psychology, 9, 2353-2367. https://doi.org/10.4236/psych.2018.99134

Received: July 13, 2018

Accepted: September 11, 2018

Published: September 14, 2018

Copyright $\odot 2018$ by author and Scientific Research Publishing Inc. This work is licensed under the Creative Commons Attribution International License (CC BY 4.0).

http://creativecommons.org/licenses/by/4.0/

\begin{abstract}
This study used Ruth's story in the Bible and reinterpreted it with feminist theological perspectives to address the related issues of Taiwanese female pastors' economic independence and autonomy. This study explored the phenomenological and contextual world of 27 female pastors' mental wellness and specifically how they deal with the hardship of financial inequality when living in a culturally patriarchal society and serving within the male dominant church system. Four themes were generated to report these female pastors' shared experiences through qualitative method. Counseling applications were provided and discussed in this article.
\end{abstract}

\section{Keywords}

Ruth, Female Pastor, Feminist, Financial Inequality, Focus Support Group

\section{Introduction}

In this study, the Bible's story of Ruth was used and interpreted in feminist theological perspectives to address the related issues of Taiwanese female pastors' economic independence and autonomy and their mental wellness living within a culturally patriarchal society and male dominant church system. The Equal Pay Act that President John F. Kennedy signed in 1963 prohibited gender-based wage discrimination (History.com staff., 2017: para. 1). However, Francine and Lawrence (2007) wrote that discrimination and gender pay gap still continue to exist. Sandberg (2013) further reported that women earned an average of 0.77 for every $\$ 1.00$ men made in 2010 . Not only in the United States have

${ }^{\star}$ Associate professor. 
women been unequally paid; a gender pay gap also is an issue in Taiwan. A recent poll showed that more female than male workers in Taiwan feel they have suffered discrimination in the workplace because of their gender. Taiwanese women on average earned $17.6 \%$ less than men. The women had to work an extra 65 days over a year's time to receive the same pay (CNA, Taipei Times, 2012). Besides being paid less than their male counterparts, Taiwanese women who work as female clergy in churches and church organizations face even more challenges for economic independence. The female pastors often need to survive not only the traditional culture but also the patriarchal church system they work within. Despite being church leaders, they also must find ways to balance church responsibilities and their traditional roles as wives and mothers. For example, if a female pastor is assigned to serve and work in a different city than her husband works, she is challenged with traditional values and expectations that a wife follows her husband to where his work resides, and she must prioritize her husband's career choice before her own career choice. According to Keller's (1996) gender role analysis, many patriarchal societies expect women to represent specific functions: (a) the life mission of a woman should be focused on marriage, family and children, (b) a woman should continue to rely on a man for her material provision and status, (c) a woman should put emphasis on her nurturing, loving function, and relationship orientation; and a woman should only be placed in roles such as mother, teacher, nurse, and other-helping roles, (d) a woman is encouraged to have an external rather than an internal locus of control. In other words, women are expected to focus on others and to please them. Instead of building upon their own achievement, women are directed to achieve by serving their husbands and nurturing their children, (e) emphasis is put on a woman's beauty, her being sexy, and other characteristics that please men; and (f) a woman is suppressed or penalized when she exhibits initiative, assertion, aggression, and ambition. Taiwanese women (female clergies included), in 2018 marching to 2019, continue to be encouraged to live a life style that depends on men's financial support. In exchange, women including female clergies are expected to play certain roles, mostly giving, nurturing, pleasing others, most often men. Despite the fact that female pastors are clergy, they are still expected to fulfill the gender roles assigned to them by their society. Because of these challenges related to these female pastors' assigned gender roles within the culture as well as the church system, five focus support groups planned with feminist counseling approach were formed for twenty seven Taiwanese female pastors who voluntarily participated in these groups and discussed how the cultures of the church and society expected them to behave and perform, especially when dealing with the financial part of their lives. The topic of the economic autonomy of their daily lives and self-esteem were addressed. This study will not only contribute in providing more depth in understanding the challenges that Taiwanese female pastors face daily but also deliver a methodology in integrating feminist theological perspective into group counseling with Christian women. 


\section{Method}

\subsection{Participants}

Focus support groups were used to collect data about Taiwanese female pastors' struggle with their financial independence. Five focus support groups were formed consisting of 27 Taiwanese female pastors (TFPs). The focus support groups were recruited through e-mails from the Female Pastor Association in Taiwan, and all members shared common backgrounds of female clergy that enhanced their communication. The participants were volunteers from Presbyterian churches in Taiwan. They had worked in a local church or church organization from 3 to 27 years. The criteria to participate in this study required participants to serve a minimum of 3 years in the Presbyterian Church in Taiwan because this is the minimum amount of time before they are qualified to be ordained. In addition, 3 years of service within the church system could potentially provide sufficient ministry experiences to participate in the focus support group.

All participants were provided with a consent form that clearly informed the focus support group members of their right to discontinue participation at any time without penalty. In addition, this form outlined the purpose of the focus group: 1) to obtain support from other group members, 2) to share their own experiences through dialogue with each other and in reference to biblical story characters, and 3) to gain more awareness regarding their own lives and church work environments. These focus support groups were scheduled on Mondays because most of the pastors have that day off on Mondays, so the sessions do not interfere with their church responsibilities. The consent form explained that each of the group sessions would be recorded, but members would have the right to read the transcription and provide feedback. Next, participants were assured that any personal or geographical data would not be revealed. Specifically, I explained that the data would only be presented anonymously and would serve to provide beneficial information from a feminist perspective regarding female pastors' financial autonomy and equality. Most importantly, a confidentiality statement emphasized that each group member was free to develop trust and understanding among other members by sharing and openly discussing any subject they desired without feeling apprehensive about revealing discreet information or fear of reprisal.

\subsection{Instruments}

Feminist Theology Perspective

The biblical woman's story of Ruth, taken from the revised edition of Today's English Version of the Bible, was implemented to address the financial independence and autonomy issues that are related to Taiwanese female pastors' mental wellness.

The Hebrew Bible often portrays God as a male deity. Women during the Old Testament period in history were viewed as Israelite property, like cattle, flocks, or other property, and often oppressed (Nelson-Pallmeyer, 2003). According to 
historical criticism, the biblical texts were written by priests and prophets; therefore, the texts represented the religious norms of the priests and prophets in the Old Testament (Greene-McCreight, 2000). Generally understood, in 2015, is the idea that an alliance existed between religious hierarchy and patriarchy. In such a patriarchal context, many feminist theologians propose the attitude of suspicion toward the traditional perspectives while developing their own theology. For example, Harris (1989) proposed to take "the attitude of disbelief, for it will nurture Awakening. ... if we want to take on our vocation to be bearers and birthers of the real God...then we must learn to practice disbelief" (p. 18). Accordingly, feminist theology denotes that "biblical texts were shaped by historical, social, and political factors" (Greene-McCreight, 2000: p. 29). Based on such analysis and understanding, feminist theologians such as Fiorenza (1992) declared that "the theological subjectivity of women in shaping and determining biblical religions and biblical women's studies have asked new questions in order to recover women's biblical heritage as religious empowerment for the present and the future" (p. 20). Fiorenza also stated that "liberation theologians and critical theorists have made us aware that all discourses represent political interests. Meaning is always politically constructed insofar as interpretation is located in social networks of power/knowledge relations that shape society" (p. 3). In this sense, feminist interpretation asks what it means to read scripture as a feminist. Furthermore, it seeks to clarify how feminist biblical hermeneutics can situate feminist readings of the Bible in such a way that they do not duplicate the patriarchal discourse of subordination and obedience.

In 1997, the Presbyterian Church in Taiwan (PCT) launched a new project called Reading the Bible with New Eyes. The New Eyes project is a movement that was initiated jointly by the three program desks of Theological Concern, Mission, and Evangelism, and Education of the Christian Conference of Asia (CCA). The philosophy of the New Eyes project was to encourage and generate a contextual re-reading of the Bible. The CCA has made specific suggestions for reading the Bible from different points of view, especially from the perspectives of women, the poor, and the marginalized (Cheng, 2004). Ruth's story was read and reinterpreted through women's perspectives instead of traditional men's perspectives. Ruth's story was used to stimulate a dialogue within a group of female pastors about their life challenges related to finances and mental wellness. According to Chrisler and Lamont (2002), "The post-modern notion of positionality is useful in feminist counseling; one must consider the location of each individual in the larger society and learn from them how the world looks from their life experiences" (p. 11). The female pastors who participated in the Using a Feminist Interpretation of the Bible's Book of Ruth to Address Taiwanese Female Pastors Financial Autonomy and Self-esteem study had many unique experiences to share. They also offered support to one another and empowered one another through this group experience. In the focus support group discussion, empowerment is a common feeling expressed by these female pastors. 


\subsection{A Feminist Commentary of Ruth and Naomi's Choice}

(Ruth 3: 1-18)

The Book of Ruth portrays a heart-warming country story emphasizing how relationships can be built in the midst of crisis and suffering. The uniqueness of the Book of Ruth is its focus on two women as main story characters. According to Leneman (2002), "It is one of the few biblical stories that focuses on women and includes extensive dialogues between two women" (p. 13). However, a reader can still find numerous patriarchal themes. For example, after Ruth and Naomi returned to Israel, they had to discover a way to find food to survive. Ruth said to Naomi, "Let me go to the fields to gather the grain that the harvest workers leave. I am sure to find someone who will let me work with him." This scene set up the perfect timing for the rich and powerful Boaz to appear in the story. He not only owned the land and workers, but also possessed the positive qualities of being considerate, sensitive, and generous. However, this romantic love story is actually embedded in a hierarchical context in which women do not have many options but are totally dependent upon men in order to survive. In addition to being a woman, Ruth was the minority among minorities for she was not only a peasant but also an immigrant. A poor woman at that time had no possibility of working and earning a living other than to pick up grain in some rich man's field. No wonder Ruth had little choice but to be grateful to Boaz's grace and to humble herself to the extent of humiliation, when she says "I am not even the equal one to your servants."

The whole plan orchestrated by Naomi was to have Ruth seduce Boaz with her beauty. Although Naomi was already old by the time they returned to Israel, she was still able to use her life-long accumulated wisdom to set up a perfect plan for Boaz to fall in love with Ruth. Naomi noticed when Boaz would work in the fields, and she told Ruth to dress up, wear the most attractive perfume, and to lie down at Boaz's feet after he finished his work and was satisfied with his dinner. This was how women at that time survived in a world that offered them no opportunity to make it on their own, especially economically. Indeed, Naomi's scheme worked because Boaz felt strongly attracted to Ruth. In the end, Naomi said to Ruth, "Now be patient, Ruth, until you see how this all turns out. Boaz will not rest today until he settles the matter." Fortunately, Boaz was fond enough of Ruth to promise her that he would make efforts to negotiate with another relative and take care of her. What if Boaz had the opposite characteristics? What if this man had been insensitive, violent, a womanizer, or macho? Ruth's story serves as a good reminder for Christians and counselors to think about the importance for women to have equal employment opportunities and how economic independence can positively affect their welfare.

In this preceding interpretation, instead of Boaz, two women, Ruth and Nao$\mathrm{mi}$, were identified as the main characters in the story. Their struggles to survive with day-to-day needs were explored as women and minorities of their times. Their strengths and limitations to overcome barriers were also discussed. This 
interpretation was designed to serve as a tool to stir up the participants' discussions. Despite the cultural differences between ancient and modern times, it is still a common theme to be a woman who deals with gender issues in a patriarchal community. This theme was used to bridge the female pastors together with Ruth, Naomi, and one another.

The preceding commentary was used as a discussion point in the focus support groups. Discussion questions were provided for the participants to discuss after reading the commentary of Ruth, which was interpreted from the Bible but not verbatim. The guiding questions include the following: 1) What is your general feedback after reading this story; 2) What is your feedback after reading the commentary provided; 3 ) Ruth (with Naomi's help) chose to find a man to help her survive financially. Was this the best choice? What other best choices do you think a woman can make and how would these options affect a woman's self-esteem; and 4) As a TFP, what is your experience when dealing with and striving for financial independence.

\subsection{Data Analysis}

Huberman and Miles (1994) derived a set of tactics for data analysis and generating meaning to 1 ) observe if there are any patterns and themes; 2) use intuitive sense; 3) see connections between groups of data; 4) integrate diverse pieces of data; 5) compare by clustering and distinguishing observations; 6) factor analysis; and 7) make conceptual/theoretical coherence, typically through comparison with the referent constructs in the literature. Bogdan and Biklen (1998) stated that "[a]nalysis involves working with data, organizing them, breaking them in to manageable units, synthesizing, searching for patterns, discovering what is important and what is to be learned, and deciding what you will tell others" (p. 157). With the consent of all participants in the five focus support groups, all sessions were videotaped; the data were collected, and then transcribed verbatim into Taiwanese and Mandarin, the languages the participants used interchangeable in the session. The transcribed data were divided into meaning units (Giorgi, 1985) with each unit representing one main meaning of participants' experiences (Giorgi, 1985). The comprised meaning units were assigned a theme based on the understanding of a unit of text in order to determine an interpretation of its essential meaning (Rennie, 2012). The similarities and differences of these initial themes as well as the text data categorized under the themes continued to be compared. Through this constant comparing and inductive process, themes could be revised, regrouped or abandoned; higher order and final themes were then merged (Rennie, 2012). Four themes were generated from the collected data. The findings are reported as follows.

\section{Results}

Theme One dealt with economic independence affecting self-esteem. Theme Two covered men as women's rescuers? Theme Three centered on double work, 
one income; and Theme Four was titled Single: Free or More Bondage?. In order to keep the authenticity and originality, the participants' quotes were presented first in participants' language then translated into English. In order to increase the trustworthiness of the study, these themes were triangulated from both the commentaries and the data obtained from the focus support groups. Additionally, themes emerging from the data were compared to the existing literature.

Theme 1. Economic independence affecting self-esteem. At the beginning of a session, one participant raised a question:

Why do you think it is that financial independence affects a woman's self-esteem? A participant immediately gave her feedback and shared her experience,

我因要委曲求全向先生拿錢而感到卑下。我生小孩後的那一段時間, 我 向教會請假, 因此那時的我沒有薪水, 我就得向先生拿錢。和我自己有 賺錢的那一段時間比起來, 賺錢的那一段時間感覺好多了, 因我不必在 經濟上依靠另外一個人。

I felt inferior when there were times that I needed to ask for some allowance from my husband. For example, after I gave birth to my daughter, I took leave from my ministry. I did not make a living at the time; therefore, I needed to ask for money from my husband. I compared with the old days when I still made a living of my own. I felt a lot better and freer back then because I did not need to financially depend on another person.

Another participant also said,

經濟獨立不只意味著一個女人有錢, 它也意味著一個女人相對擁有的自 我價值與成就感。

Financial independence does not just mean that a woman has money, it also provides for a sense of self-worth and it is a validation of a woman's accomplishment.

One participant agreed that economic independence definitely affects a woman's self-esteem by stating,

一個人不能經濟獨立, 就容易成為另一個人控制的目標。

When a person is not financially independent, it is easier for that person to become a controlled object by another person.

She continued to say that in her church, most female church members work. Those who are stay-at-home housewives must consider their husbands' thoughts and feelings toward their spending, because after all, they need to ask him for money which sometimes makes them feel like beggars.

One participant shared her situation and her worry as well. She and her husband both worked and each had their own personal incomes; however, their spending habits and styles were different. When her husband began complaining about her spending, she would stand up for herself since she brought money into the family as well. She had recently considered trying to become pregnant, but according to her doctor's suggestion, she needed to plan on taking a leave to re- 
lax from her work stress and increase the possibility of getting pregnant. However, she worried that if she did take a leave, she would risk becoming more controlled by her husband since she would not be making money.

One participant strongly expressed,

我真的覺得經濟獨立帶給我自主權, 我可以決定我要做的事情, 或者是 我也不需要看人家的臉色。

I really feel that economic independence allows me to be my own life's master. I get to make decisions for myself and I do not need to please others.

In summary, participants expressed their experiences and ideas about how financial independence positively affected their lives, marriages, and how they feel about themselves.

Theme 2: Men: Women's rescuers? Does Ruth have other choices besides being remarried? Some participants thought that Ruth did not have much freedom to choose whether or not to be remarried. In Ruth's time, women did get their life stability through marriage. Even in 2015, many women stay in unsatisfied relationships because they are not economically independent and therefore need a financial supporter.

Most of the participants agreed that Naomi was a wise woman. They admired her wisdom to use the resources she had to help Ruth as well as herself to survive. Some participants thought,

學習像拿俄米一樣善用資源, 利用大男人的自大求得生存, 我們的社會 還是以男性為主的社會，善用男人的資源。

Since our society is a patriarchal society and men get most of the powerful positions, it is unavoidable that we learn to work with and even use men as a resource to survive.

Some participants thought differently. One shared her faith that God would take care of her financial needs. She believed that the only thing a Christian needs is to have faith in God.

我媽媽獨自一個人撫養四個小孩, 很辛苦, 我一直覺的說, 依靠主, 上 帝一定會祝福。

God will prepare enough for us. My mother raised four children by herself. It was hard, but we were so blessed. God still took care of us.

A question that was raised for everyone to think about was, 當一個女人沒有很多其他的經濟選擇, 而只能靠男人賴以維生之時, 如 果這個人沒有好好對待她呢? 她怎麼辦呢?

If a woman has only limited choices and needs to find a man to depend on financially, what if it turns out this man only financially supports her but mistreats her in other areas of life?

Overall, participants expressed the understanding of the limited options that Ruth and Naomi had as women in a patriarchal society. They even felt empa- 
thetic because they could relate to these two ancient women. Through Ruth and Naomi's story, the female pastors' voices were found and their own stories were told and heard.

Theme 3. Double work, one income. The participants shared issues relating to the phenomenon of double work, one income, such as salaries and the arrangement of their positional status. Several participants told similar experiences when they interviewed with churches that sought pastors. For example, one said,

當有教會來邀請我們去牧會時, 都會先說好沒有兩份薪水, 一份或一份

半。並且教會也說要聘的封的那一位就是男的那一位。

Some churches came to ask me and my husband's intention to minister to their churches; they always told us in advance that they could only afford one person's salary. They also told us that they wanted my husband to be the primary minister because they mainly were looking for male ministers.

A participant shared her female colleague's story with the group regarding a pastor couple. The wife was gifted in many ways. She was not only a pastor, she also played the piano and conducted the church choir. However, due solely to her gender, she was not paid by this church where she and her husband both ministered. Further, the church elders did not pay her the respect that she deserved as a pastor. This is a case in which a female pastor fulfilled all the requirements that a church could ask of a good pastor, but she was not recognized because of her gender.

Another participant said,

教會即使有能力, 基於傳統觀念一個牧師就要配一個牧師娘, 教會也不 願意付兩份薪水。

Even a wealthy church would not pay two salaries to couple pastors. Traditionally, hiring a pastor usually means that the church would get a free pastor wife.

Within this context, female pastors who marry male pastors become only assistants to their husbands without getting salary or retirement benefits like their husbands. The discrimination practice is unfair because these women are as qualified as their husbands. They received the same seminary training and served the church. However, their positions and identities were not respected or recognized. Female pastors have no benefits, yet this issue has been ignored by the church. Steil (2001) stated that paid work for women is an important factor relating to their self-esteem and independence. According to Gutek (2001), "The right to equal access, equal opportunity, and equal compensation in the workplace, it was reasoned, would result in relatively more independence for all women and would equalize power in their relationships with men, in their families, and in society" (p. 379). A female pastor's experience agreed with Gutek. She wished to have a divorce due to marital violence. However, she could not leave her husband because she did not have a paid position at the time. She had no job because she was expected to play a gender role as her husband pastor's 
assistant. Another participant responded to this issue by saying,

所以我就講女傳道、女牧師不是一份兩份的問題, 是經濟自主的問題。

It is just not an issue whether a pastor couple gets one or two salaries. It is more of an issue of whether a woman gets her economic autonomy.

After this comment, the group continued to discuss how to advocate for female pastors' equal pay, especially when their husbands are also pastors and those churches they minister to are only willing to pay one salary. A participant stated,

當我們講這個的時候, 傳委就會警告我說不要再講, 你會害女傳以後都 找不到工作。

I was warned once not to talk about this issue, because this would jeopardize pastor couples' benefits even more. Talking about this issue may cause female pastors more difficulties in finding a ministry in which to work.

One participant shared an enlightening perspective:

像你啦, 你如果你自己的退休制度, 萬一啦！你自己退休還可以..., 你 現在依附在妳先生旁邊的, 經濟上、退休制度也是一樣啊, 我都沒有聽 說過, 牧師娘跟牧師離婚後, 牧師娘自己還有退休制度的, 沒有啊, 完 全就是依附在先生嘛!

I never heard that a pastor's wife would receive any benefit or retirement income if she got divorced with her husband. The welfare of these women is dependent on their husbands' welfare. This makes it harder for women to choose to live independent and autonomous lives.

Female pastors who are married to pastors often are treated unfairly by churches. These women ministered churches with either no official positions or no pay because churches automatically assign the main minister roles to these female pastors' husbands. Only one salary was paid and it was for the husband's ministry work. These female pastors worked but were paid nothing or unequally. Churches have granted and enforced this type of injust culture.

Theme 4: Single: Freedom or more bondage? A participant described a talk she had with the presbytery commissioner,

我的謝禮一定是兩個月或三個月時才領一次。牧師說, 因為是女孩子所 以沒不需要食家活口, 這讓我覺得外界常有的聲音是妳是女性又單身, 所以不用要求這麼多。

You are single. You do not need as much money as people who have family; therefore, I am assigned to minister to a church that cannot pay me a salary every month. I get paid every two or three months.

One participant shared that she ministered to a sign language church. Therefore, because most of her church members were deaf and poor, her salary was very basic and limited. She also was supporting her parents financially. She shared,

我要食我自己也要飬爸爸媽媽, 在整個經濟上就蠻有壓力的。媽媽有時 
也勸我找對象時如果年紀大我一點或者是鱞夫, 但經濟上若可以幫助我 就沒有關係。變成說, 考慮重點在經濟能力上。

I feel burdened financially. I am still single. My mother sometimes asks me to consider marrying a man who can support me financially even though he might be divorced...or a widower. It is like the focus of my marriage is to find a rich man who can financially support me.

A participant strongly voiced her opinion,

如果我需要靠婚姻來得到一個更好的社會經濟地位, 那我算什麼東西啊?

What is my worth and value if I obtain a better social economic status by marrying a husband who is already financially stable?

Another participant said,

在經濟獨立上, 我很自主, 拿到謝禮時我先規劃, 哪些錢要做什麼, 剩 下的我就會為所欲為地花完。我覺得這樣很快樂。所以當我活得越好時, 就越不會受到周遭影響, 有時, 反而是周遭的人會受我影響。

I am still single. Even though I have to face certain stress to get married because of my age, I try to live a joyful life. Financially I am independent. I get to budget my money the way I want. It turned out that the more I can live a happy and self-content life, the less people around me try to change me.

Female pastors who are single may not face the hardship as the theme three has described. However, they faced unique challenges for being not married. They still were paid less and unequally because of their gender.

Azar and Vasudeva (2006) stated that "The role of paid worker is a source of self-esteem, self-identity, and social rewards” (p. 111); the authors' research determined that professionally employed women had significantly higher self-esteem than unemployed women. Throughout the group sessions with the TFPs, opinions expressed by the participants were varied; they read Ruth's story from various viewpoints and demonstrated different values when discussing the topic of economic independence. Some held more traditional values whereas others were more traditional. For example, some participants thought marriage is one of many ways for women to obtain a better social economic status through men if they do not do illegal or immoral things. One said,

上帝對每一個人有不同的計畫。女人透過不同的方式找到幸福。女人靠 找到一個男人來照顧他不見得是不好的; 但也不見得每一個女人都要按 照傳統價值觀所定的去找一個丈夫才可以得到幸福。

God has different plans for every person's life. I think women look for happiness through different means. It is not necessarily a bad thing for a woman to look for a man to take care of her; yet it is not necessarily a good path for every woman to look for a husband as the conventional values have taught us.

On the other hand, some participants thought that women paid a very high price in order to better their social economic status through marriage. As 
Kelly-Zukowski (2005) said, "There is no doubt that many cultural limitations were imposed on women in ancient Israel. In many ways they were oppressed. Yet in other ways we can see them as possessing the wisdom and ingenuity to work within those confines" (p. 40). Ruth and Naomi's story is a noteworthy example to demonstrate how women lived in a context that culturally limited them and oppressed them tremendously. However, Ruth and Naomi were able to survive by using their wisdom to break through their bondage. The context that today's women are dealing with may be the same in some perspectives and different from Ruth's context in other perspectives. The challenges for today's women are similar to those challenges faced by women in ancient times: How to fight the oppressive patriarchal culture using the strength they gain from their wisdom?

\section{Discussion: Applications in Counseling Settings}

This interpretation of the Book of Ruth focused on exploring the gender issues centered on a woman's identity and her ability to obtain financial stability through marriage. A woman's identity and value are determined by her marriage status, both in the Old Testament and today's Taiwanese context. One also can emphasize that to a certain extent, the bonding between Naomi and Ruth helped break the bondages of being widows in their society. Leneman (2002) stated that "Ruth is also the only biblical text where the word 'love' is used to define the feeling of one woman for another" (p. 13). Trible (1978) also valued what happened between the two women in the Book of Ruth. She stated, "One female has chosen another female in a world where life depends on men. There is no more radical decision in all the memories of Israel" (p. 17). Many Taiwanese single women face the pressure of abiding by traditional and patriarchal values of the society such as marrying by a certain age, usually between twenty to thirty years-old. An interpretive piece offered in this article can be helpful to empower women who wish to remain single.

Harding and Hintikka (1983) stated, "What counts as knowledge must be grounded on experience. Human experience differs according to the kind of activities and social relations in which humans engage. Women's experiences systematically differ from the experiences upon which knowledge claims have been grounded" (p. x). The contribution of Using a Feminist Interpretation of the Bible's Book of Ruth to Address Taiwanese Female Pastors' Financial Autonomy and Self-esteem is significant because Taiwanese female women are underrepresented in the existing literature. The voices of Taiwanese female pastors can contribute to the scant literature currently available in 2018 by providing data to both American and Taiwanese counseling professionals: counselors, theoreticians, and researchers, to consider when discussing Christian women's mental health issues within culture and context.

Counselors may consider this type of focus support group that uses biblical stories about women when working with female clerics. Providing interpretive commentary could add another dimension to the traditional counseling process 
among women with similar spiritual and religious background. The shared experiences and common vocabulary would enhance group members' mutual understanding and help them to participate actively in the group process. The process can bring in curative factors such as universality which demonstrates that we are not alone in our misery or "problems and benefit the group participants". The applicable group counseling steps are recommended as follows.

Step one: Decide on the participants. The selected participants should be able to contribute to group discussions through their ministry and life experiences. For example, having at least three years of work experience in a local church or church organization can ensure that the participants have sufficient and rich experiences to share with the group and to understand other group members.

Step two: Decide recruiting methods and recruit participants. E-mails, invitation cards, and telephone calls are excellent ways to invite female pastors to participate in the group. Another good way to invite potential group members is through female pastor associations if there are any available. The group size should fall between four to seven group members, a size that would provide each participant with ample time and opportunity to share their own stories. The format should be closed group. After the participants are selected, the members should remain the same from the beginning to the end of the group. No new members can join in the middle of the group sessions. This would allow group members to do some meaningful work within a trustworthy and supportive group environment.

Step three: Prepare the setting of the focus support group. Select a warm and inviting setting for the group. Consider a familiar place that is in close proximity to the majority of group members. Coffee, tea, and snacks can be prepared for the group members.

Step four. Make selections from the Bible. The group facilitator may use the biblical selection provided earlier in this article or may select other women's stories from the Bible in addressing the same topic-economic independence.

Step five: Make a selection of commentaries to the stories or write the commentary.

Step Six: Conduct the group sessions. Pay attention to how church system reflects and endorse the patriarchal values of the greater culture and mistreat female clergy.

\section{Conclusion}

Using a Feminist Interpretation of the Bible's Book of Ruth to Address Taiwanese Female Pastors Financial Autonomy and Self-esteem explored and addressed the issues of how Taiwanese female clergies strive for their identity and their self-esteem by overcoming economic inequality. The women's stories in the Bible were used as a tool to facilitate and help the female clergies focus and discuss their day-to-day experiences in regard to their self-esteem and the financial aspect of their lives. This study focused on female pastors' mental well-being 
based on the idea that feminist theology is not simply about God anymore; it is also about the well-being of people, since the core belief of Christianity is that lives are from God, and God has strong compassion toward human beings. The feminist perspective offers an egalitarian theological perspective which can be fostered to contribute to the mental health of Christian women, in this case, female pastors. The female perspective offers hope to Christian women as they challenge the traditional beliefs toward gender and redefine their roles and their identities in society. Economic inequality and injustice among genders is clearly prevalent in greater Taiwanese society and is reflected in the Church, due to the patriarchal values that society holds, and these issues must be continually addressed and challenged in different forms.

\section{Conflicts of Interest}

The authors declare no conflicts of interest regarding the publication of this paper.

\section{References}

Azar, I. A. S., \& Vasudeva, P. (2006). Self-Efficacy and Self-Esteem: A Comparative Study of Employed and Unemployed Married Women in Iran. The German Journal of Psychiatry, 9, 111-117.

Bogdan, R. C., \& Biklen, S. K. (1998). Qualitative Research in Education: An Introduction to Theory and Methods (3rd ed.). Boston: Allyn and Bacon.

Cheng, Y. (2004). Life and Mission in the Church of Taiwan. http://english.pct.org.tw/Article/arti020520.htm

Chrisler, J. C., \& Lamont, J. M. (2002). Can Exercise Contribute to the Goals of Feminist Therapy? Women \& Therapy, 25, 9-22. https://doi.org/10.1300/J015v25n02_02

CNA (2012). Women Still Discriminated against at Work. Taipei Times. http://www.taipeitimes.com/News/taiwan/archives/2012/03/07/2003527197

Fiorenza, E. S. (1992). But She Said: Feminist Practices of Biblical Interpretation. Boston: Beacon.

Francine, D. B., \& Lawrence, M. K. (2007). The Gender Pay Gap: Have Women Gone as Far as They Can? Academy of Management Perspectives, 21, 7-23. https://doi.org/10.5465/amp.2007.24286161

Giorgi, A. (1985). Phenomenology and Psychological Research. Pittsburgh, PA: Duquesne University Press.

Greene-McCreight, K. (2000). Feminist Reconstructions of Christian Doctrine: Narrative Analysis and Appraisal. New York: Oxford University Press.

Gutek, B. A. (2001). Women and Paid Work. Psychology of Women Quarterly, 25, 379-393. https://doi.org/10.1111/1471-6402.00036

Harding, S., \& Hintikka, M. B. (Eds.) (1983). Discovering Reality: Feminist Perspectives on Epistemology, Metaphysics, Methodology, and Philosophy of Science. Dordrecht, Holland: D. Reidel.

Harris, M. (1989). Dance of the Spirit: The Seven Steps of Women's Spirituality. New York: Bantam Books.

History.com staff. (2017). Equal Pay Act. https://www.history.com/topics/equal-pay-act 
Huberman, A. M., \& Miles, M. B. (1994). Data Management and Analysis Methods. In N. K. Denzin, \& Y. S. Lincoln (Eds.), Handbook of Qualitative Research (pp. 428-444). Thousand Oaks, CA: Sage.

Keller, E. F. (1996). Reflections on Gender and Science. New Haven, CT: Yale University Press.

Kelly-Zukowski, M. (2005). The Subversiveness of the Marginalized Women of Scripture: Models of Faith and Action for Twenty-First Century Women. Gender Issues, 22, 29-42. https://doi.org/10.1007/s12147-005-0003-5

Leneman, H. (2002). The Voices of Ruth and Naomi: Cultural Transformation through Librettos and Music. European Judaism, 35, 13-25. https://doi.org/10.3167/001430002782266333

Nelson-Pallmeyer, J. (2003). Is Religion Killing Us: Violence in the Bible and Quran. New York, NY: Trinity Press International.

Rennie, D. L. (2012). Qualitative Research as Methodical Hermeneutics. Psychological Methods, 17, 385-398. https://doi.org/10.1037/a0029250

Sandberg, S. (2013). Lean in: Women, Work and the Will to Lead. New York, NY: Alfred A. Knoph.

Steil, J. M. (2001). Family Forms and Member Well-Being: A Research Agenda for the Decade of Behavior. Psychology of Women Quarterly, 25, 344-363.

https://doi.org/10.1111/1471-6402.00034

Trible, P. (1978). God and the Rhetoric Sexuality. Minneapolis, MN: Augsburg Fortress. 